\title{
HISTORICAL MAP OF ALBANIAN VILLAGES: A TOOL FOR HARMONIZING CENSUS DATA THROUGHOUT THE 20 ${ }^{\text {TH }}$ CENTURY
}

DOI: https://doi.org/10.18509/AGB.2017.02

UDC: 528.94:911.373:]314(496.5)"19"

\author{
Alain Jarne ${ }^{1}$, Martin Schuler ${ }^{2}$ \\ ${ }^{1,2}$ Ecole Polytechnique Fédérale de Lausanne (EPFL), Switzerland \\ Corresponding author: alain.jarne@epfl.ch
}

Submitted: January 2017, Accepted: March 2017, Published: August 2017

\begin{abstract}
The present article deals with conceptual and methodological questions at the base of a research project of settlement history of Albania in the $20^{\text {th }}$ century. We focus our interest on the identification of all local units and their population. In order to get a complete cover of the country and historical comparability we investigated, as far as possible, the enumeration of all villages of Albania and the number of their inhabitants, but also their localization and administrative status as well as their spatial delimitation. On the one hand, our work refers on an important corpus of official statistics issue of all censuses held in Albania between 1913 and 2011, partially never published. On the other hand, the large use of all available geographical maps dating from different periods up from the 1930s permitted to spatialize the statistical information, to localize demographic information and to compare and to improve the data.
\end{abstract}

Key words: Albania, population, villages, map, census;

\section{Introduction}

In the context of our research on settlement history of Albania, we tried to get a complete cover of all villages of the country at the moments when censuses have been conducted. Our work refers on an important corpus of official statistics issue of all censuses held in Albania between 1913 and 2011. A large use of all available geographical maps dating from different periods up from the $1930 \mathrm{~s}$, permitted to spatialize the statistical information. In this paper, we will give a short overview on the quality of the statistical sources and the cover and extend of the 19 censuses from which exist complete or partial information on population at local level.

In several respects, Albania represent a challenging context for historical demographic research. Before the 1920's, only partial and unevenly reliable records are available. Afterward, many censuses were conducted, especially after 1945 , but changes in the administrative network (the last having come into force in 2015), lack of precise boundaries and the difficulty of obtaining large-scale mapping and disaggregated statistical information (which have not been published) make it difficult to gather and consolidate the data. As for the last two censuses of 2001 and 2011, data exist up to the individual level, but access is not necessarily easy, and spatialization and codification poses certain difficulties. But fortunately, the task is made possible by the permanence, throughout the $20^{\text {th }}$ century, even in a rather vague sense, of the village as a reference level, which allows the reaggregation of the data according to administrative changes. The work thus describes the collection of statistical information available at the village level between 1912 and 2011, the work of location of these villages, and finally, the harmonization of the data. 


\section{Statistical sources}

today, of which a dozen, indicated in the following table, proved to be accessible for

There exist about twenty enumerations between the end of the Ottoman period and

Table 1: Censuses and enumerations carried in Albania in the $20^{\text {th }}$ century, availability of data at village level (X).

\begin{tabular}{lllcl}
\hline Year & Type* & Carried out by & Villages & Observations \\
\hline 1913 & E & $\begin{array}{l}\text { Grand quartier général } \\
\text { hellénique }\end{array}$ & X & $\begin{array}{l}\text { Spatial extent: "Northern Epirus" (southeast of } \\
\text { Pogradec-Himara diagonal) }\end{array}$ \\
\hline 1918 & C & Austro-hung. military adm. & X & Northern and central regions to Vjosa river \\
\hline 1918 & E & French military adm. & X & "Confins albanais", present prefecture of Korçë \\
\hline WWI & $?$ & Italian military adm. & - & Vlorë region. Quoted by Bërxholi (2000), p. 105 \\
\hline 1923 & C & Albanian state & - & \\
\hline 1927 & R & Albanian state & X & Religious affiliation \\
\hline 1930 & C & Kingdom of Albania & - & Some available but dispersed results \\
\hline 1940 & C & Italian military adm. & - & Quoted by Bërxholi (2000), p. 106 \\
\hline 1943 & C & German military adm. & - & Quoted by Bërxholi (2000), p. 106 \\
\hline 1945 & C & People's Republic of Alb. & X & Population and gender \\
\hline 1950 & C & People's Republic of Alb. & X & Population and gender \\
\hline 1955 & C & People's Republic of Alb. & X & Population and gender \\
\hline 1960 & C & People's Republic of Alb. & X & Population and gender \\
\hline 1969 & C & People's Republic of Alb. & X & Population and gender \\
\hline 1979 & C & People's Republic of Alb. & X & Population and gender \\
\hline 1989 & C & People's Republic of Alb. & X & Population, gender, households \\
\hline 1994 & R & Republic of Albania & X & Population, households \\
\hline 1996 & R & Republic of Albania & X & Population, households \\
\hline 2001 & C & Republic of Albania & X & Populations, internal migratory movements, etc. \\
\hline 2011 & C & Republic of Albania & - & To request \\
\hline & & & * E=Enumeration; C=Census; R=Register \\
\hline
\end{tabular}

The first set of data consists of the surveys carried out by the occupying powers in their different zones during the First World War. With the exception of the town of Vlorë and its hinterland (roughly hundred settlements) and frontlines (Mokra, Skrapar), approximately ninety percent of the territory is covered. The most important survey (by covered territory, quality, and completeness) is the Austrian-Hungarian census of 1918 [1]. The other two sources, covering the south and east of the country, are the "Statistique ethnologique de l'Epire du Nord" collected under the auspices of the Hellenic Headquarters in 1913, and published in 1919 [2], and the "Tableau des villages administrés par la France dans les Confins albanais", published by Bourcart in 1921 on the basis of the 1918 enumeration [3].
The first record has been realized in October 1912 by the Greeks who occupied the south of present Albania, called by them "Northern Epirus" (Vorio Epirus). Enumeration has been carried out in a context of conflict and territorial claim. The essential concern of the measure has been the legitimization of the Greek occupation, the "ethnological" dimension consisting in counting "Hellenes" and "Albanians", according to religious affiliation and not, as the record suggests, on ethnic or linguistic definition. The second census held in Albania has been conducted by the French administration in the "Confins militaires albanais". At the end of 1916, in order to make a junction between the French front of Macedonia and the Italian front in Albania, French troops entered Albania, established their headquarters in Korça and deployed a local administration. This French 
administration will last until the summer of 1920 and will cover all the former kazas of Kortcha and Starova, part of those of Berat, Skapari, Monastir and Elbasan. In 1918, the administration recorded its population, some 122 '000 people. Jacques Bourcart, a geographer engaged in the campaign who returned to Albania after the war, published these results for each village in 1922 as an appendix to his book "Les Confins Albanais administrés par la France 1916-1920".

The third and most important census of the time was conducted by the Austrians in the north and the center of the country. After the initial occupation of these territories by the Serbs and Montenegrins in 1915, Bulgaria's entry into the war precipitated their retreat. The Austro-Hungarian army occupied the country until the Vjosa River, to the south of which were the Italians, who occupied since 1914 the strategic island of Saseno, the city and the port of Valona and its hinterland. The Austro-Hungarian interests in Albania had preceded the entry into the war; thus their networks were already well established in the Catholic area of northern Albania.

As soon as they arrived, they managed the conquered land as a real colony, determining the territorial-administrative organization, building roads, organizing post and finances, and carrying out a complete census of its population.

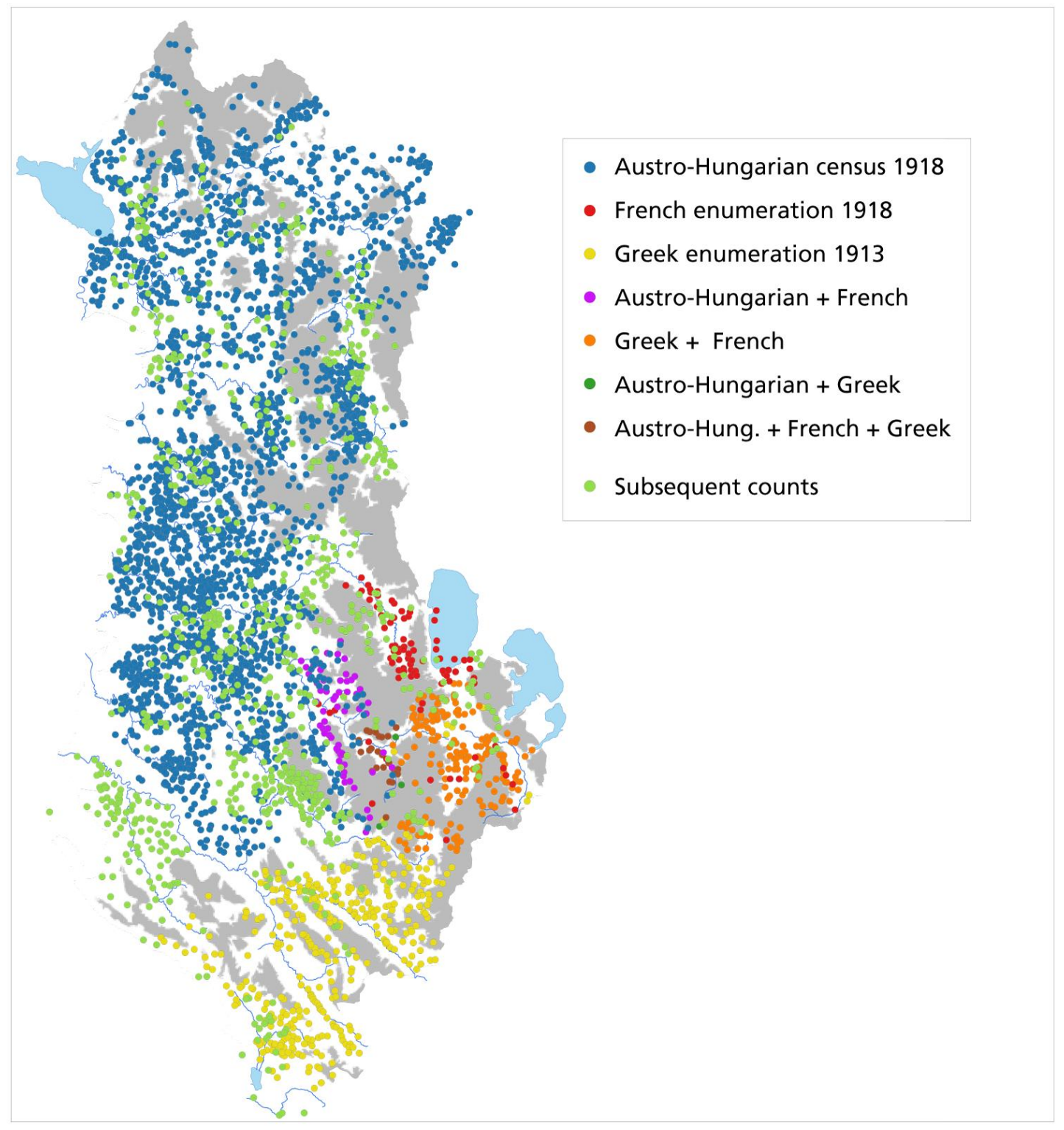

Map 1: Location of the villages and hamlets enumerated by the different occupying powers in 1913-1918 and those that appear in the subsequent counts (green). 
This census differs from those described above since it has been organized by a real specialist, Franz Seiner from Graz. Arrived in 1917 in Shkodra, Seiner directed carefully the well prepared operation; he disposed of the pre-war experience of the Consuls who had themselves collected or encouraged the collection of scientific data. The basic results on the village level were published by the Austrian Academy of Sciences in 1922. A sample of individual records has been given out by Kaser et al. in the 2000's [4].

Only partially used by Albanian researchers (poorly known and reputed to be incomplete), these data seem to be very rich. They never have been spatialized on the local level nor compared between themselves or with the subsequent censuses. The principal spatial lack is the region of Valona/Vlorë; according to Bërxholi [5], a census has been hold by the Italian occupier, but we couldn't find any trace of it up to now. Data from some conflict zones are also missing (Skrapar in particular). For all other parts of the country, villages detected in later censuses are in fact new settlements: new towns, agricultural cooperatives, new neighborhoods which have become separate villages. Critical work on these sources has still to be done, especially on their validity in the context of war (destruction of villages, displacements of populations, refugees, etc.).

In the unstable years of the inter-war period, the young Albanian state conducted two censuses in 1923 and 1930, but results did never have been published. According to Gruber [4], the original sheets of 1930 census should still be available, but they are kept in different archives. An important actor of statistical collection at this time has been Teki Selenica. Engaged as an inspector of the Ministry of the Interior at the time of the 1923 census, he became SecretaryGeneral of the Council of Ministers and headed the 1930 census. In 1928, he published a book that remains the main source of statistical data from that period, and in particular, it presents the population register data for 1927 for each village, including religious affiliation [6]. In the absence of data from censuses, data from 1927 are used for this work.
The communist period is the richest, since seven censuses were organized between 1945 and 1989 (1945, 1950, 1955, 1960, 1969, 1979 and 1989). While the questionnaires have evolved over time, especially according to the needs of the fiveyear plans and the political agenda (disappearance of questions on religions in 1960), the collection at the local level seems to be consistent over time. Figures at local level never have been published. The geographer Arqile Bërxholi carried out in the archives a handwritten record of the population by village, and proposed a harmonization at the level of the 374 communes and municipalities in force before the territorial reform of 2015. Finally, we obtained the access to the data of the 2001 census from the Albanian statistical office (Instat), and we hope to get the same data for 2011.

\section{Spatialization of censuses}

The absence of a precise registration of the administrative boundaries has been a common problem for all Albanian censuses in history, from the enumeration conducted by Siner up to the census of 2011. The methodological orthodoxy of collection of statistical data is difficult to achieve; it would recommend the use of enumeration areas embedded in existing administrative units as geographic base for the census.

\section{Franz Siner's list of place names}

Franz Siner came up against this type of problems when he arrived in Albania in 1917. The first observation he made was the need to create a repertory of places, which did not yet exist (or only very partially) and which seems to him an essential element in order to organize a serious census [1]. This repertory includes all villages, as well as associated hamlets, isolated farms, mills, which makes it possible to determine the limits of villages in a sufficiently precise manner. This list had been used for a campaign preceding the census, in which the buildings have been counted and the population estimated. Comparing results of this estimation with those of counts made the previous year, Siner notes a significant 
improvement: villages and whole districts had been forgotten. An important work of writing is also carried out in order to produce a reference document, which is complicated since many names exist in two or three languages (Turkish, Slavic, Greek, and Italian, especially in border regions). They are pronounced differently by the villagers

(Kthella/Thkella, Rubigu/Robiku/Rrbiku, Leshi/Lezjia), etc. The final version of the list includes 114 communes, 1794 villages and nearly 4000 hamlets. In the mountains of the North, where settlement is dispersed, it is common to find villages consisting of 8 or 9 places with distinct names. Siner describes several problems such as the cross-checking of regional and local names, the fact that they are often interchanged (Siner deplores this fact even when he is assisted by educated informants, such as Catholic priests or missionaries). He mentions also a special problem occurring in the North where confusions are the result of the attribution to the places of names of the Fis (i.e. parental communities). If, as Doja [7] points out, "the social structure is often based on a spatial partition of the territory, inhabited by tribal groups with lineage", it is not an absolute rule. From the $19^{\text {th }}$ century onwards and the intensification of demographic and social processes, increased population movements created "a gap between relations derived from kinship and relations based on neighborhood and territory". The conesquence is that a name associating a lineage community with the valley it comes from can be given to villages or hamlets outside it, that the name of a village may be carried by a farm in a neighboring village, and therefore more generally that the crossing of these social and spatial inheritances ethnonyms and toponyms - often results in a great confusion, source of many errors. The establishment of correct place names could therefore only be done very gradually. As part of our project, almost all of the villages have been located more or less precisely, whereas only about a quarter of the hamlets and farms have been identified, what shows a strong evolution of the "micro-names".

\section{Contemporary cadastral zones}

The closest territorial definition of a village is maybe today the "cadastral zone". Traditionally, two cadastral systems coexisted. The first, essentially present in the towns, consisted of a simple register of properties. The second, used for the registration of agricultural land, included a cadastral map at 1:5000. Between 1976 and 1991 , private property was prohibited by law. As early as 1991, the government began recovering cadastral information and passed a law in 1994 on redistribution of land. The territory is divided into cadastral zones (approximately 3000 ), each of which has a register of properties which combines a map and a title of property ("kartella"). The list of cadastral zones corresponds in fact to that of the villages; it was used by the Instat for preparing the 2001 census. The map of the spatial extent of these cadastral zones is therefore a central document to reconstruct coherent village boundaries. But this map is not complete: it covers about half of the territory, including most of the populated areas. The plain areas are thus covered. On the opposite, cadastral areas are sometimes completely missing in the mountainous regions, and where they exist, they rarely or partially integrate the commons (pastures and forests) and the unproductive areas. It is not uncommon for zones to overlap.

\section{Spatial definition of inter-village boun- daries}

Before communism, the management and ownership of the commons was regulated by the Kanun, under the gaze of the ancients. As elsewhere in the Ottoman Empire, "[...] land regime recognized multiple layers of ownership. [...] In this complex land regime, villages constituted the defining units with regard to taxation and the award of new lands for almost the entire existence of the empire" [8]. Specific areas were the property of groups of brothers (vllazni) and clans (fis). Beyond a certain distance to the dwellings, forests and mountain pastures were the common property of the different villages, and still further, the land outside the coproperty of villages were owned by the bajrak (district) [9]. Traditional mountain societies had a very strong and long tradition of collective management of these areas. The 
procedure for defining borders met the rules of Kanun. This system prevailed until the end of the Second World War. The socialist order then extended to the northern mountains, and claimed to eliminate the Kanun institution, the patriarchal structures and the semi-feudal class of the Bajkaktars [9].

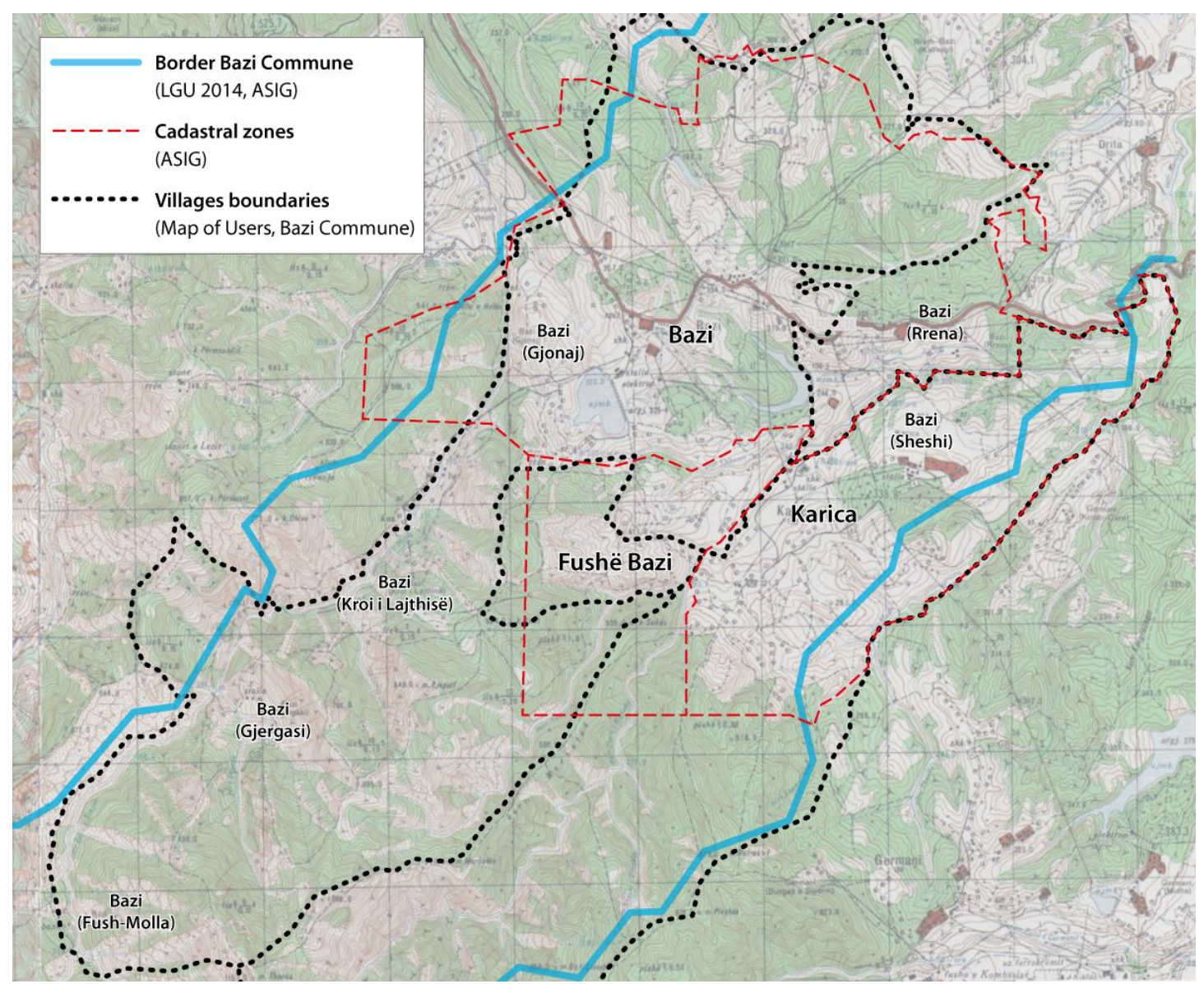

Map 2: Different definitions of communal and village boundaries

But post-1991 developments have shown that many aspects of local culture have survived communism and that the Kanun precepts have largely supported the reorganization of mountain societies in the difficult years following the collapse of the regime. This is also the case for the memory of the old boundaries, what, in some respects, has facilitated the return to private property in comparison to other regions. But in the commons, many conflicts arose (grazing rights, logging) because of the contradiction between the state ownership derived from the communist regime and the practice of customary rights, as well as due to the inability of the state to impose clear administrative boundaries between villages. According to Kola and Zeneli [9], an important difficulty resides in the principle of the retrieval of the limits between the excooperatives as communal borders, rather than the retrieval of pre-communist inter- villages limits. In the framework of the project to transfer ownership of commons from the State to the communes, inventories of traditional village boundaries have been undertaken. On map 2, we have represented the result of such an inventory in a part of the commune of Baz (Mat district), and superimposed on the borders of the communes and cadastral zones as published on ASIG portal.

In the case of Baz, the different types of limits show a partial coherence. When obvious natural barriers occur, there is a corresponding overlap between the cadastral zones and the traditional boundaries: this is the case for the village of Karica, situated between two streams. But this case reveals the approximate nature of the communal boundary (in blue), which does not follow the watercourse southeast of Karica. Elsewhere, the superposition of traditional boundaries and cadastral zones is poorer. On 
the other hand, there is a good crosschecking of the toponymical information used for our mapping and traditional boundaries for isolated farms outside the cadastral area (Fush-Molla, Gjergasi and Kroi i Lajthisë). The map shows the logic of the cadastral zones which cover the populated areas, that of the village boundaries which integrate the village commons, and that of the communal boundaries, which, in order to cover the whole territory, continue in the mountains (bottom left, out of the map) on the eastern slope of Mali i Skenderbeut.

\section{Spatialization of recent censuses}

The spatialization of the last two censuses done by Instat is mentioned in various documents relating to them [10]. For 2001, Instat had problems to obtain maps or written documents from the previous census (1989, communist regime), and it had to afford changes and indeterminacy of administrative boundaries, the effects of considerable population movements and the presence of numerous informal constructions on the fringes of the cities. In case of urban areas, cadastral maps have been available, but in rural areas, updated lists of heads of households were used by referring to the 1998 Census of Agriculture. Most often, the cadastral zones correspond to the village [10]. Digital mapping (approximate boundaries of communes and municipalities, Tirana enumeration areas, points to locate villages) was carried out only after data collection. In 2011, the method was improved and extensive use of digital mapping was made for the preparation and collection of data. However, the problem of village borders has not been solved: the generation of enumeration areas has been done automatically on the basis of population estimation, taking into account natural obstacles and communal limits. In both cases, the allocation of the population to the villages was done on the basis of selfdeclaration. If the Enumerator Handbook of 2001 does not formally mention this fact, the 2011 edition states: "As there are no formal boundaries for villages and towns, you need to know what the location of the dwelling is" [10]. To our knowledge, the mapping of these declarations, possible for 2011, has not been made: it would provide interesting information on the quality of this spatialization.

\section{Topographical cartography}

Since no census has accurate, complete and available information on spatialization (maps, cadastral extracts, etc.), we have proceeded to mapping by considering the following geographical bases: collection of georeferenced toponyms and associated cartography, geodata (administrative units, cadastral zones), and mainly topographical maps. All relevant geographic data have been gathered in a Geographic Information System (GIS). Two main families of topographic maps have been relied upon: Italian cartography from the 1930s (1:50'000) and Albanian cartography from the second half of the communist period $\left(1: 10^{\prime} 000\right.$ for coastal regions, elsewhere $\left.1: 25^{\prime} 000\right)$ [11] as available on the portal of the Albanian Authority for Geographic Information (ASIG).

The Italian Military Geographical Institute based in Florence produced between 1928 and 1939 a set of 90 maps covering the entire territory of Albania. These maps were partially revised in 1941-42 on the basis of aerial photographs from 1937. Most of the maps have been produced by the Italian army's own surveys. In the Southeast (Mallakastër-Korçë-Sarandë), Italians conceived a provisional cartography in 1939, after the outbreak of the war against Greece. These maps are based on ancient surveys of the French (1:50'000), Austrian (1:25'000) and Italian (1:50'000) army maps made during the First World War, as well as those of the Border Commission (1922-1925), with the aim of rapidly completing coverage. Deferred on the Italian trigonometric network and updated rapidly on the basis of 1937 aerial photos, they are less accurate and less exhaustive in terms of content (religious buildings for example are only partially reported). The main interest of these maps lies in the very rich toponymy, what allows to trace ancient villages and the numerous villages whose names have changed over time because of the "nationalisation of space" [12]. Names that sound foreign (Greeks, Turks) have been changed in favor of Albanian names. For cities and large 
villages, maps show usually an Italianized form of names.

The other series of maps consist of the Albanian production of the 1970s and 1980s and recently published on the national cartographic portal (ASIG). Unfortunately, the sheets are not dated, and their age is obviously quite variable. They give a quite contemporary vision of the territory, which most often integrates the deep transformations of the landscape that marked the communist period: drainage of the marshes and other land reclamation, urbanization, large dams, etc. Although they do not contain any administrative boundaries, their very rich toponymy compensates for this deficit by associating the name of the main village with all the micro-names (describing hamlets or isolated farms). The double comparison of these associations with the lists of the Austrian census of 1918 and the modern delimitation of the cadastral zones gives an idea of the stability of the spatial definition of villages. The high correspondence between them is one of the keys for the success of harmonization of census data. For the coastal plains, there is also a 1:10'000 cartography which is even richer in toponyms, sometimes useful on the outskirts of towns in the great plains and on the outskirts of agricultural cooperatives.

\section{Historical map of Albanian villages}

For the purposes of our reconstruction work, for example to visualize and understand the differences in the allocation of hamlets to villages over time, it was essential to set the boundaries as precise as possible on a map offering complete coverage of the territory, without gap or overlapping. The basic unit is each village appearing at least one time in the tables of the dozen census counts considered.

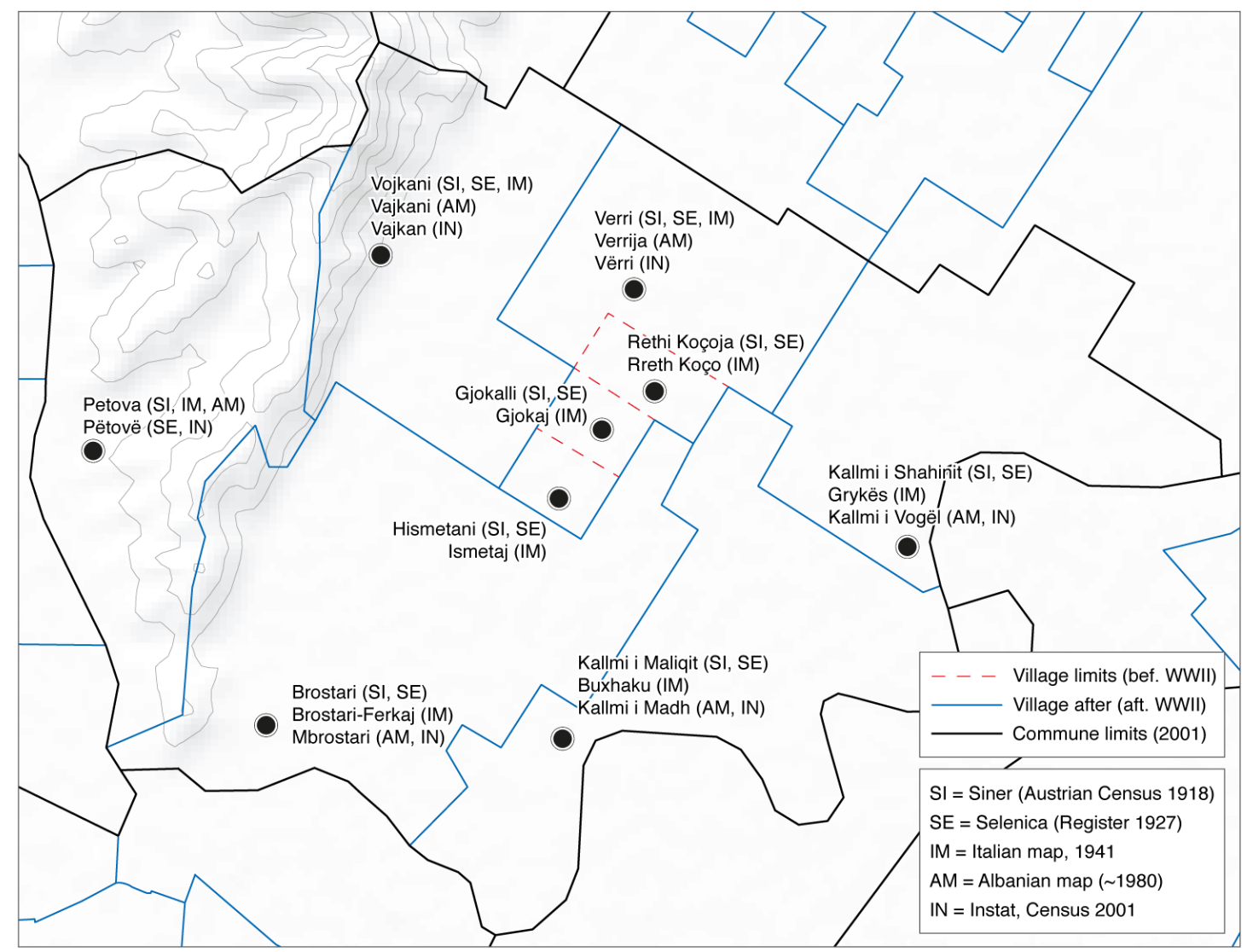

Map 3: Commune and village limits at Mbrostar (north of Fier). Some place names remain unchanged, some other change significantly.

A little more than 3350 units are in the repertory, compared to the 2977 villages of the 2001 census. For coding, the reference chosen is the 2001 census, since the data collection done by Arqile Bërxholi reports the information at this level. In addition, the 
codification of the villages done by Instat and by the Cadaster are quite comparable. The numbering is done by adding a digit to the four digits cadastral codes (which correspond to the initial alphabetical numbering of the villages). For example, the village of Buzëmadhi, at the confluence of the Vjosë and Shushices rivers northeast of Vlorë, is coded 1341. The polygon corresponding to its center is coded 13410 , while the codes of three hamlets in Fusha e Buzëmadhi which appear independently in the tables of 1927 but have merged since are coded as follows: Glonçi (13411), Murtajasi (13412) and Tojkani (13413). On this basis it is possible 1) to aggregate the data for each census or intercensal interval, or 2) in cases where the old census unit is larger than the current one - villages or cooperatives have emerged, or data from an old census were only available for a village group - to aggregate the polygons to correspond to a formerly relevant territory. In the first case, the old village may be associated with a new one, for example by retrieving its name from the Italian map, which may allow it to be located within a cadastral area, and/or because it appears as a hamlet on the Albanian map. In the second case, Siner lists are often useful when micro-toponyms of hamlets attributed to villages can be located on Italian maps, this gives the spatial extension of an ancient village and allows comparison with more recent data. This work is tedious and naturally, in certain cases there remains some uncertainty and interpretation. However, there is in general a strong congruence between the different sources. If not, cases are documented in the database. For mapping it was decided to aim for complete coverage of the territory by the village units (which, as we have seen, does not fully correspond to the land reality). When available, the cadastral areas are the main reference. Out of them, cartography relies on higher administrative boundaries, on micro-names and by subsidiarity on natural boundaries (rivers, ridge lines, etc.). In lowland areas, the use of cadastral areas induces village boundaries modeled on the orthogonal framework of the improved crops, which does not correspond to the prewar land tenure structure.

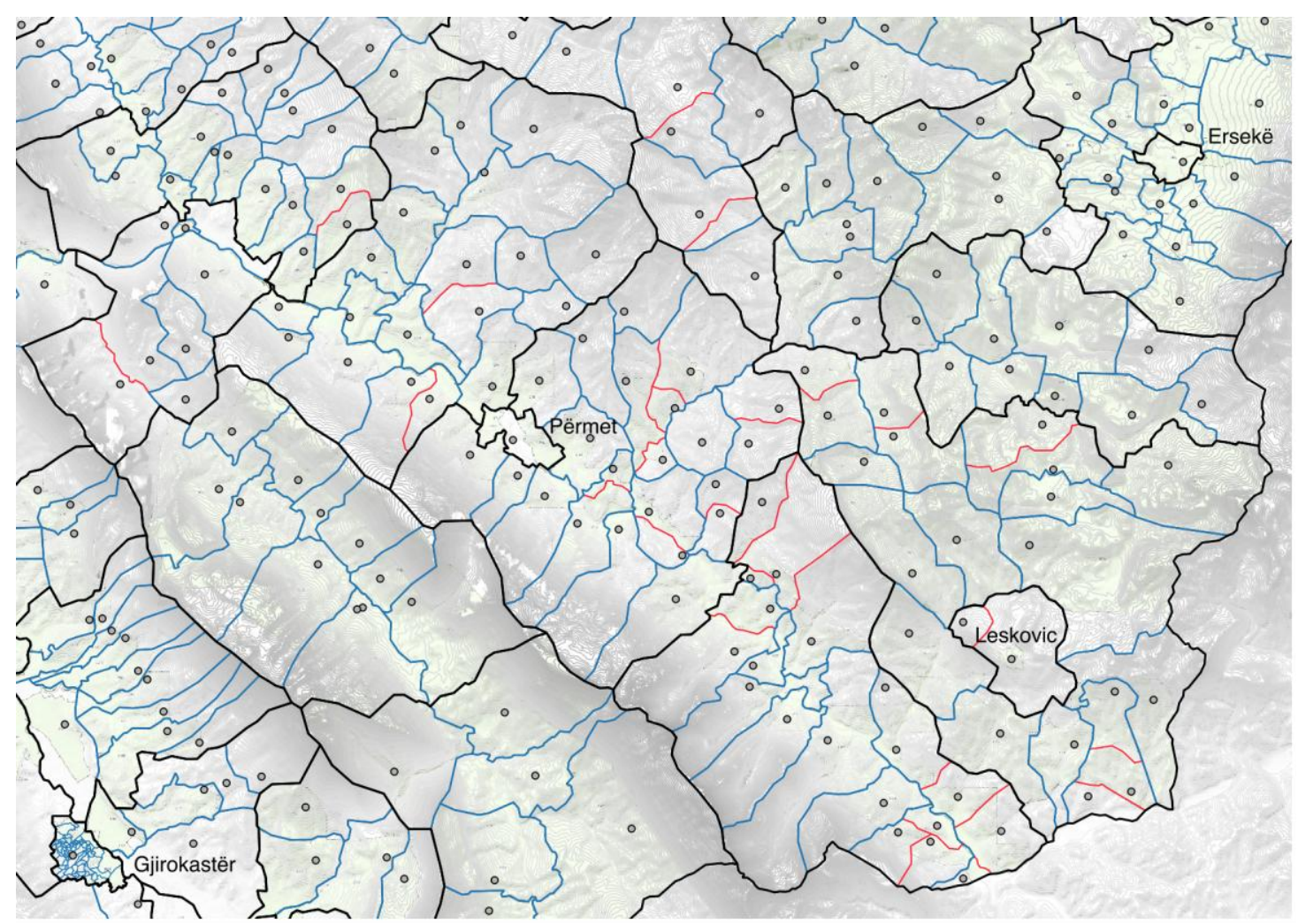

Map 4: Extract from the historical map of Albanian villages: the black strokes correspond to the communes/municipalities as they stood until 2014. In blue, the boundaries of the villages listed in 2001 , in red, the boundaries of ancient villages. In green, the surface of cadastral zones; in grey, the relief, one of the criteria used to draw boundaries outside cadastral zones. 
On the basis of the historical map of villages, a new dimension of Albanian statistical patrimony may be explored in two ways: 1) trying to approximate internal mobility - especially during dictatorship through reconstruction of migratory balance at local level, 2) comparing finer patterns through analysis of origin-destination information available in recent censuses (2001 and 2011) and - which is uncommon - in the first modern Albanian census, the one conducted by the Austrians in 1918. At the present moment of our research, we have finished the collection of census data on the level of villages and we have already largely completed the historical harmonization of population data. As shown, the geolocalization of villages and borders is accomplished. The further steps will include an analysis of the demographic patterns through the periods by adding available information on births and deaths and balance of migrations during the different periods of the $20^{\text {th }}$ century. By referring to different spatial classifications and typologies local phenomena will be confronted to the general spatial tendencies operating by periods and regional context.

\section{References}

[1] Seiner Franz, Ergebnisse der Volkszählung in Albanien in dem von der österr.-ungar. Truppen 1916-1918 besetzten Gebiete (Schriften der Balkankommission, Linguistische Abteilubg, vol. XIII), Vienna und Leipzig, 1922.

[2] Carte ethnographique/statistique ethnologique de l'Epire du Nord en 1913, Grand quartier général hellénique, 1919.

[3] Bourcart Jacques, L'Albanie et les Albanais. Paris: Éditions Bossard, 1921.

[4] Kaser Karl, Siegfried Gruber, Gentiana Kera, and Enriketa Pandelejmoni, 1918 census of Albania, Version 0.2 [SPSS file]. Graz, 2016.

[5] Bërxholi Arquile, Regjistrimet e Përgjithshme të Popullsisë në Shqipëri. Vështrim Historik (Censuses in Albania. A Historical Perspective). Tirana: Akademia e Shkencave, Qendra e Studimeve Gjeografike, 2000.

[6] Selenica Teki, Shqipria më 1927 / L'Albanie en 1927. Tiranë: Shtypshkronja Tirana, 1928.

[7] Doja Albert, "A propos de la diversité locale des traditions culturelles albanaises", in $L a$ Ricerca Folklorica, no 38, 1998.

[8] Schull Kent F., M. Safa Saraçoğlu, and Robert Zens, eds. (2016), Law and Legality in the Ottoman Empire and Republic of Turkey, Indiana University Press.

[9] Kola Haki and Zeneli Gazmend, Enhancing Tenure Security Through Support the Communities to Improve the Laws on Transfer of State Public Property (Forest and Pasture) to the Communes, Tirana, 2008.

[10] Albania Census Report 2001, presented by the association Demobalk; Albania, Population and Housing Census 2001 in Albania, presented by Instat at the Conference of European statisticians (2006), Digital Mapping for the 2001 Population Census in Albania: Technical Aspects and Benefits, presented by Instat at the Conference of European statisticians (2003), as well as Census 2001 Enumerator Handbook and all 2011 field manuals given out by Instat.

[11] Pasha Myslim (et al.), Portreti gjeodezik dhe hartografik i Shqipërisë, Tiranë, 2003.

[12] Clayer Nathalie, "L'albanisation des toponymes dans l'Albanie de l'entre-deux-guerres ou les méandres d'une lente construction étatique", in Gilles de Rapper et Pierre Sintès, Nommer et classer dans les Balkans, EFA, 2008, pp.237-255. 